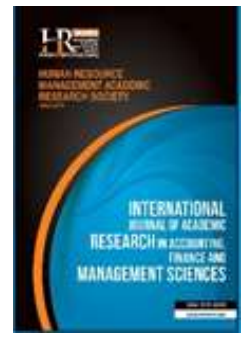

International Journal of Academic Research in Accounting, Finance and Management Sciences

Vol. 9, No.3, July 2019, pp. 118-127

E-ISSN: 2225-8329, P-ISSN: 2308-0337

(C) 2019 HRMARS

www.hrmars.com

To cite this article: Baskaran, S., Kumar, S. K. B., Tangaraja, T., Mahadi, N. (2019). Conceptualizing Strategic Ethical Decision Making: Cultural Traits as Moderator, International Journal of Academic Research in Accounting, Finance and Management Sciences 9 (3): 118-127

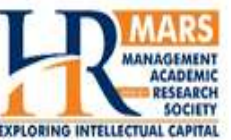

http://dx.doi.org/10.6007/IJARAFMS/v9-i3/6346 (DOI: 10.6007/IJARAFMS/v9-i3/6346)

\title{
Conceptualizing Strategic Ethical Decision Making: Cultural Traits as
} Moderator

\author{
Shathees Baskaran ${ }^{1}$, Saravin Kumar Binu Kumar², \\ Thanabalan Tangaraja ${ }^{3}$, Nomahaza Mahadi ${ }^{4}$ \\ 1,2,3,4 International Business School, Level 10, Menara Razak, Universiti Teknologi Malaysia, \\ Jalan Sultan Yahya Petra, 54100 Kuala Lumpur, E-mail: shathees@utm.my (Corresponding author)
}

\begin{abstract}
It has turned out that business organizations are forced to deal with a complex business environment. In such cases, recognizing and dealing with ethics, especially in the strategic decision-making process has become an unavoidable circumstance to the organizations. Well documented ethical scandals displaying unethical behaviours in the strategic decision making within the organization can be traced to several decades. From this evaluative viewpoint, plainly the ethical misconducts are basically not tolerable. While there are continuing debates in enlisting factors driving unethical behavior in the organization, strategic decisionmaking attributes and cultural traits within the organization flagged as a few prominent factors in understanding this phenomenon. Therefore, this study is an attempt to suggest a conceptual framework connecting strategic decision-making attributes and unethical behaviour. In order to improve the predictive validity of the framework, cultural traits are proposed as a moderator in understanding the relationship between strategic decision-making attributes and ethical behaviour. This framework is suggested based on the synthesis of relevant supporting literature underpinned by Deontology Theory. Although this study suffers empirical investigation, it still shed some theoretical direction in understanding unethical behavior among organizations.

Keywords Strategic Decision Making, Individual Attributes, Social Environment, Work Environment, Cultural Traits, Adaptability, Involvement, Consistency, Mission, Unethical Orientation

Received: 14 July $2019 \quad$ C The Authors 2019

Revised: 22 Aug 2019 Published by Human Resource Management Academic Research Society (www.hrmars.com)

Accepted: 28 Aug 2019 This article is published under the Creative Commons Attribution (CC BY 4.0) license. Anyone may reproduce, distribute, translate and create derivative works of this article (for both commercial and non-commercial purposes), subject to full attribution to the original publication and authors. The full terms of this license may be seen at: http://creativecommons.org/licences/by/4.0/legalcode
\end{abstract}

\section{Introduction}

Managers are continuously identifying alternatives to maintain the competitive advantage of an organization in response to increasing competitive pressure in the marketplace (Li and Liu, 2014). Wood (1991) illustrated the right thing to do in an organization is integrating ethics into strategic goals. In addition, strategic management has always been concerned about the ethical principle which focuses on objective statements that go beyond time, countries, and religion (Robertson, 2008). Strategic decision making is a process where a particular action is being made to create an organization objective. Effectiveness of integrating both ethics and strategic management in an organization solely depends on the strategic way of decision making. Strategic decision making is crucial in sustaining organization growth and effectiveness. Besides, strategic decision making is the most effective way of developing short and longterm strategies. This strategic decision making should impose ethical criteria's where it aids in maximizing 
organizational profit (Key and Popkin, 1998). Incorporating ethical decision making helps in retaining low business risk with long term survival.

The beginning of the 21st century was defined by immense importance towards organizational culture and business behavior in the economic field (Militaru and Zanfir, 2012). The idea of culture in organizations started to be implemented widely from the year 1960 through the year 1980s, although it was already implemented by inventive individuals even before that (Sinclair, 1993). Organizational culture reflects a general understanding of right or wrong behavior which directly influences the ethical environment of an organization (Akaah, 1993) and could lead towards unethical behavior. An organizational culture allows the organization to stay competitive in the market (Şengül et al., 2015) reflected by organizational goals or key performance indicators (Heesen, 2015).

Ethics of organization has an equal amount of impact as the organization culture. Apart from the moral status in an organization, the presence of moral intent among the associate is the query that earned substantial importance (Sinclair, 1993). Past studies found that people tend to act unethically unconsciously and fail to notice them (Gino, 2015). An organization and its business operations which are driven by high ethical standards, rooted in integrity will acknowledge the importance and prominence of a cohesive ethical culture in defining what it means to be ethical while integrating personal and organizational values (Çelikdemir \& Tukel, 2015). Hence, it has become an essential role for the managers to ensure that ethics are not compromised in the organizations in order to not only save the organization but also to sustain its reputation (Daft, 2010). There are continuing issues about whether ethics is an individual phenomenon or organizational phenomenon. For some scholars (e.g. Watson, 2003, Soares, 2003), ethics is an individual phenomenon while a few others (e.g. du Gay, 2000) claim it to be integrated into the organizational structure. There are many factors including organizational and situational factors (Hunt and Vitell, 1986) and individual factors (Ferrell et al. 2010) that affects ethical behavior in the organization. According to Rampersad (2003), strategy development in the organization must consider ethics by integrating them into performance metrics.

\section{Literature Review}

\subsection{Unethical Behavior}

Ethics are viewed as the primary driver for ethical conduct and there is a growing interest to provide ethical guidelines to carry out duties with professionalism under pressures to adhere and maintain the compliance (Rahahle, 2017) in an attempt to combat unethical undertakings in the organization. Unethical behaviour is the action that affects an individual or organization which is morally unacceptable to the community (Soltes, 2016). Behaviour as such can disrupt an organizations business which hinders them from achieving goals. A study by Kahn (1990) defines that ethical behaviour in an organization was influenced by the individual and the organization itself. It further explains that for individual, emotion and lack moral value that promotes unethical behaviour. On the other hand, for the organization aspect, the reward system and code of conducts will be the cause for unethical behaviour (Kahn, 1990). As articulated by Bradford and Garrett (1995), the model emphasizes that unethical organizational behaviour can be influenced by the accusation of the external party on a corporation. The main aim is attaining profit without taking into account any moral principle which leads to them to be unethical. It is an approach where it demotivates corporation in order to be ahead of others. Tang and Chiu (2003) explained that the monetary approach can influence the unethical behaviour of an individual. Monetary is a boost of motivation for employees to achieve organization goal (Milkovich and Newman, 2002). Money is the value that drives an individual to work ethically in fear of them losing their reward. In addition, Trevino, Butterfield, and McCabe (1998) also explained that ethical climate and ethical culture is another model that influences ethics in an organization. There are several climates that which is known as the social environment that directly cause an organization to be unethical. Thus, there are many factors influencing the unethical behaviour and it should be overcome with the appropriate approach in order to drive success.

Unethical behaviour can be categorized as an act that can have a negative effect on other individuals which can be either morally unacceptable or illegal (Jones, 1991). In an organizational context, unethical behaviour of managers and employees are affected by three key components which are ethics program, ethical culture and ethical climate (Kaptein, 2011). Males and females clearly have different moral 
orientations (Betz et al., 1989). Behavioural ethics research share two supported assumptions which are morality are dynamic and easily influenced. The second assumption is unethical behaviour is the result of individuals who value morality but fail to resist the temptation for dishonest act although failed to recognize immorality in the decision made (Bazerman and Gino, 2012). Studies were also conducted on how the love of money, pay satisfaction, job changes and organizational commitment to unethical behaviour in Hong Kong (Tang \& Chiu, 2003). Rational-bureaucratic control theory grounded the assumption that both managers and employees tend to behave unethically due to lack of understanding of what is expected of them (Kaptein, 2011). In addition to that, predicting unethical behaviour is more relatable to the theory of planned behaviour compared to the theory of reasoned action (Chang, 1998).

\subsection{Strategic Decision-Making}

Decision making is often the most crucial aspect of making a choice. Beach (1993) defined that the best decision can be made when there are options from a set of choice which contains more than two options. According to Beach, image theory highlights the important role in portraying good decision making requires screening. This broadens the view before making a specific decision and allows all aspect to be covered. Tversky and Shafir (1992) further explained that in spite of having many alternatives in decision making, none of the alternatives are accepted. This defined that the option deliberated is the insufficient and best way of making a choice is through personal or social perspective. Decision making in the current context where information is gathered become more towards mathematical science (Figuera et al., 2005). They also emphasize mathematical science have a more formalize a way of thinking to where a decision made should be transparent. This way all the decision made is clear and there won't be any issue contradicting with the current decision being made. There are many criteria in decision making that measure the important decision being made first. According to Saaty (2008), another study shows that there are many intangibles that require to be traded off in order to carry out a decision. The theory Analytic Hierarchy Process (AHP) is where the measurement of tangible is done in order to comply with the objective of decision-maker. Besides that, a study focuses on the significance of strategic decision making where the most common framework used is SWOT (Strength, Weakness, Opportunity, and Threats). It helps in identifying the organization external and internal environment thoroughly before an effective decision is being made (Ketchen et al., 2004). Therefore, all the data from both internal and external perspective can be integrated into pursuing a good strategic decision-making process for the organization. El-banna and Child (2007) also mention that internal decision making plays an important role in determining if the firm is making an effective strategic decision. Finally, good decision making can incorporate success to the organization. However, it is important to be mindful that neither a reliable portrayal of insignificant information nor an unfaithful portrayal of pertinent information enables users to make sound judgment; hence it is still deemed to be unethical (Soyinka et al., 2017). Based on the discussions above, the following research proposition was developed:

Proposition 1: There is a significant relationship between strategic decision making and unethical behaviour.

Decision making can be view in several aspects such as individual attributes, social environment, and work environment. This aspect influences each process of decision making from a different perspective.

\subsection{Individual Attributes}

Bommer et al. (1987) describes the model in which individual attributes comprise are moral values, motivational drive, and personality. It is based on the individuals own perception that drives them to make any decisions. Kohlberg $(1969,1971)$, further strengthens the model by illustrating the pre-conventional category that causes individuals to not take account of the rightfulness of the decision but rather focuses on individuals own physical need. Individual own needs have become the cause where decisions are influenced without focusing on the actual measures. Another study by Freeman and Gienfink (1979) articulated that the moral level is affected by the gender differences where females are more focusing on moral reasoning. It is said that moral consideration is a good approach to good decision making. In the context of Ward and Wilson (1980), they highlighted that good decision can be made when an individual is motivationally orientated. This way the individual does not get influenced by any pressure from external 
parties in making decisions. Summarizing that overall individual attributes focus on the motivational factor that allows them to carry out good decisions. Studies have shown that Individual attributes in decision making are more likely to behave unethically. Due to their personal ethical standards bellow organization expectation, they tend to make decision-based on the assumption (Soutar et al., 1994). Individual behave unethically by making the decision for their own personal gain while neglecting the consequences of an organization. Based on the discussions above, the following research proposition was developed:

Proposition 1a: There is a significant relationship between individual attributes and unethical behaviour.

\subsection{Social Environment}

The social environment is where culture, humanistic and societal value that significantly aid in decision making. According to Brady (1985), there is a model focus on society values have a huge influence on the current decision made. He further explained that decision making considering the social environment is important so that it does not put the society in a bad situation. An example explained that social environment is taken into consideration when the decision for nuclear power and genetic engineering was being made (Brady, 1985). Game theory is a neuro-economic approach in decision making where the one making a decision should understand and explain the situation. It focuses on rational thinking where the decision made can reach the outcome of others and not affecting them (Sanfey, 2007). A study highlighted that during the decision making social dimension are being ignored as generation these days are more individualistic. During decision making externalize should be taken into account in order to be aware of the social consequences Paez and Scott (2007). Therefore, the social environment should have been considered before making a decision in order to prevent society from having any effect. Decision making is very crucial in a social environment aspect as a decision made by an individual that harms the society might influence others to follow in the same phase. Unethical behavior as such will influence the whole society around them. Based on the discussions above, the following research proposition was developed:

Proposition 1b: There is a significant relationship between social environment and unethical behaviour.

\subsection{Work Environment}

The work environment is another factor that can be considered in decision making where it influences an individual to be ethical or unethical (Bommer et al., 1987). One of the work environments that determine the employee's behavior is the organization culture. Organization culture in the context of Dunham and Pierce (1998) is the people, structure and the process of the corporate. The structure is defined as the reward system of the organization which affects the motivation of the employee. On the other hand, Wheelen and Hunger (2006) explain the corporate decision in emphasizing on short term goal profit shift the work environment into a new stressful level which causes employees to be unethical. In contrast, employees have to be more aggressive and make decision rashly in order to meet organization goal which leads to unethical behavior. The good working environment promotes good ethical behavior among employees. A working environment which strives to achieve success in a short period of time will like to manger to make an unethical decision (Wheelen and Hunger, 1984). The organization will be able to achieve this short-term goal but it might hinder others. Based on the discussions above, the following research proposition was developed:

Proposition 1c: There is a significant relationship between work environment and unethical behaviour.

\subsection{Cultural Traits}

Organizational culture has numerous definitions. The most common term defined by Lundy and Crowling (1996) would be "the way we do things around here". According to Schein (1996), organizational culture can be defined as a set of values and beliefs that could lead to behavioural norms. On the other hand, Schein (2004) defines organizational culture as "the set of shared, taken-for-granted implicit assumptions that a group holds and that determines how it perceives, thinks about and reacts to its various 
environments". This definition reflects three different perspectives of organizational culture which are organizational culture are transferred through socialization, behaviour at work and multiple level engagements. The organization's internal environment is reflected by its culture and interpreted by the beliefs of the managers and employees (Aycan et al., 1999). In support, Furham and Gunter (1993) state that organizational culture as internal integration and coordination. In addition to that, organizational culture also provides a shared system of meaning which could form a mode of mutual understanding and communication. According to Ovidiu-lliuta (2014), strong values are the base of any company to form a strong organization as it relates to operating procedures of efficient resources utilization. These can lead to forming a sustainable vision of a company as each organization has its own unique set of values and culture. Robbins (1996) also mentioned that strong culture contributes shared values which aligns everyone in the organization are on the same track. There are several models developed to illustrate the link between variables and phenomena of organizational culture. According to Schein (1996), the essence of Denison's model is the assumptions and hidden belief that reflects the deepest levels of organizational culture. Denison's model determines the correlation of organization more on surface-level values and their unambiguous practices. These kinds of values are more reachable and reliable than artefacts (Denison, 2000). This organizational culture model is extracted from broadly defined cultural traits which are adaptability, involvement, consistency, and mission. There is a high possibility for employees in an organization to behave unethically and it is realized frequently. Organizational often rewards an individual behavior which violates ethical standard (Sims, 1992). Besides that, managers also do play a part in the way an employee think which could foster unethical behavior (Wolfe, 1988). This is supported by the statement that "moral personality" of the organization doesn't influence unethical behavior but those principles of right and wrong (Ewin, 1991).

Adaptability has a positive relationship towards unethical behavior based on previous studies as it is relatable to the restructuring of processes and environment in an organization. Restructuring in an organization does change the behavior to align with the new structure. The past studies on the second cultural trait which is involvement also portray positive relationship towards unethical behavior. This is supported by the statement which shows a strong connection between involvements, ownership through empowerment. Empowering employees in an organization could establish human capability (Ahmad, 2012). The third cultural trait of consistency reflects positive relationship towards unethical behavior as it is related to internal values in an organization. Consistency strongly influences internal integration of an organization which escalates towards common mindsets (Senge, 1990) and a clear set of values this could reduce unethical behavior or intention. Mission also has a positive relationship towards unethical behavior as rational-bureaucratic control theory grounded the assumption that both managers and employees tend to behave unethically due to lack of understanding of what is expected of them. Mission in an organization gives the employees on how their task could lead to the organization's performance and goals. Based on the discussions above, the following research proposition was developed:

Proposition 2: There is a mediating effect of cultural traits on the relationship between strategic decision making and unethical behaviour.

The main model used to determine the dimensions of cultural traits were based on Denison's organizational cultural traits which were developed by determining the traits by studying the linkage to effectiveness and analysis of CEO perceptions of these traits. The traits used are involvement, consistency, adaptability, and mission. These traits were developed mainly to study the effectiveness of the organization. The following section will discuss each dimension.

\subsection{Adaptability}

Organizations which are well distinguished than other organizations are performing well due to their ability to recognize and react to their surroundings. Processes and behaviours are restructured which aids them to adapt (Ovidiu-lliuta, 2014). Highly integrated organizations are the ones which are the hardest to change (Kanter, 1983). Organizations which are good at adapting usually fuelled by their customer, willing to take a risk and learn from their mistakes, and capable of creating change (Meredith, 2001).

Proposition 2a: There is a mediating effect of adaptability on the relationship between strategic decision making and unethical behaviour. 


\subsection{Involvement}

Participation and involvement will create responsibility and a sense of ownership. Ownership leads towards a great commitment to an organization and capability to operate under self-governing conditions (Denison and Mishra, 1989). In addition to that, Ouchi (1980) suggested that implying these principles could generate an organizational form called "clan". Besides that, empowering employees in an organization able to establish human capability and build their organizations around teams (Ahmad, 2012).

Proposition $2 b$ : There is a mediating effect of involvement on the relationship between strategic decision making and unethical behaviour.

\subsection{Consistency}

The effective organization tends to have a strong culture which is integrated, consistent and coordinated (Ahmad, 2012). Implicit control systems which are based on internal values are more effective in achieving coordination compared to the external control system which is related to rules and regulations (Denison and Mishra, 1989). Consistency strongly influences internal integration and stability which leads towards a common mind-sets and conformity (Senge, 1990). Successful organizations have a clear set of values which helps the manager and employees' inconsistent decision making aligned towards the organization goals (Ovidiu-lliuta, 2014).

Proposition 2c: There is a mediating effect of consistency on the relationship between strategic decision making and unethical behaviour.

\subsection{Mission}

One of the dimensions of organizational culture model created by Martins (1987) to describe the importance of leadership towards the ideal organization was mission and vision. A successful organization will have a clear mission that could show their employees on why and how their task could help the organizational performance (Ovidiu-lliuta, 2014). The changes in an organization's mission could lead to changes in other aspects of the organization's culture (Ahmad, 2012).

Proposition 2d: There is a mediating effect of the mission on the relationship between strategic decision making and unethical behaviour.

\section{Conceptual Framework}

Decision making is the most important situational approach which an affect the individual behavior ethical or unethically in an organization. According to Becker and Becker (2001), "The term "deontology" is a modern combination of Classical Greek terms, and means the study or science (logos) of duty, or more precisely, of what one ought to do (deon). In contemporary moral philosophy, "deontology" is used most commonly to refer to moral conceptions which endorse several theses regarding the nature of duty (the right), the nature of value (the good), and the relationship between the primary ethical concepts of the right and the good."

Deontology Theory has mentioned the action done based on rules should be judged morally. Additionally, it indicates applying a similar guideline for each one in all conditions. In his theory, moral behaviour offers a discerning system of general standards and principles that oblige and guide everybody. This imperative reveals what must be done independent of our wants and the truism must be equipped for being apprehended without inconsistency (Beauchamp and Childress, 2009). Therefore, truth-telling is consistently an obligation, regardless of whether the other party has the privilege to know or whether it may create harm to the innocent human being (Drane, 2002). On these ground, deontologists hold that lying is wrong even if a lie would accomplish great good for individuals and society (Beauchamp \& Childress, 2009). One's decision made considering organization goals should be morally done in order to prevent unethical behavior. Nevertheless, the criticism continues to exist in view of Deontology Theory that deontology can't itself accommodate goals of contentions among at least two parties who significantly have opposing views (Amer, 2019). 
Several other theories have also discussed the importance of ethical behavior. For instance, a study by Donaldson and Preston (1995) highlights that the decision-making process made through stakeholder theory guidance indicates that moral values should be taken into account to prevent unethical behavior. On the other hand, there were two other theories underpinned in this study which are social learning theory and theory of reasoned action. Bandura's (1977) social learning theory indicates that people tend to learn what behavior is expected by observing the behavior of role models. In the context of the organization, managers and supervisors should portray ethical behaviors so that their subordinates could follow and avoid unethical behavior. Finally, the theory of reasoned action indicates that an individual's behavior is determined by their behavioral intention to perform that behavior (Ajzen and Fishbein, 1977). Unethical behavior, in this case, could be an outcome of the intention of an individual at that specific moment. Frankena (1963) stated there should be a balance between the good and bad. Decision made by an individual to another that affect negatively be morally wrong. Therefore, any decision as such will create unethical behavior. The organization should be guided by these theories in order to ensure the decision to create any unethical behaviour. Based on these discussions, the following conceptual framework was proposed in the study:

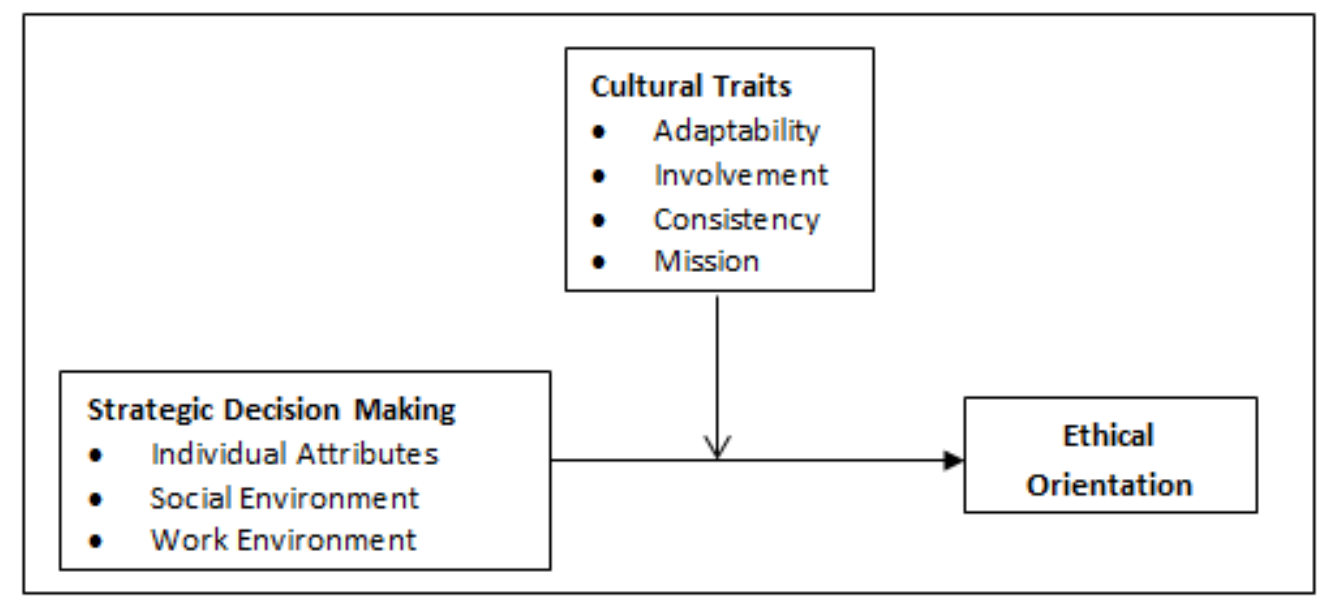

Figure 1. Conceptual Framework

\section{Conclusions}

Business ethics by and large deals with judging whether practices accomplished by organizational citizens can be considered ethically satisfactory (Ferrell et al., 2008). Leaders in the organizations are regularly looked with circumstances that require sound ethical decision-making capacity. Deciding the suitable course of action to take when encountered with a troublesome moral situation can be a challenge. Subsequently, it is progressively critical to concentrate on the best way to settle on the correct choices, given a particular circumstance. Having an appropriate mechanism and cultural traits, therefore, becomes essential to promote ethical strategic decision making in the organization. In a nutshell, the decision can either harm or benefit the organization depending on the situation. The best ethical decision being made can change the perspective of individuals in the organization to practice ethical work culture. Organizations must ensure that ethical theories are being implemented in the business to work in a positive direction. Additionally, it is evident that organizational culture does play a huge role in the overall performance of an organization. Cultural traits do have a positive impact on values, behaviors, and ownership of an individual. There are possibilities of unethical behavior of employees in an organization which is relatable to these cultural traits.

\section{References}

1. Ahmad, M. S. (2012). Impact of organizational culture on performance management practices in Pakistan. Business Intelligence Journal, 5(1), 50-55

2. Ajzen, I., \& Fishbein, M. (1977). Attitude-behavior relations: A theoretical analysis and review of empirical research. Psychological Bulletin, 84(5), 888. 
3. Akaah, I. P. (1993). Organizational culture and ethical research behavior. Journal of the Academy of Marketing Science, 21(1), 59-63.

4. Amer, A. B. (2019). Understanding the Ethical Theories in Medical Practice. Open Journal of Nursing, 9(2), 188-193.

5. Aycan, Z., Kanungo, R. N., \& Sinha, J. B. P. (1999). Organizational culture and human resource management practices: the model of culture fit. Journal of Cross-Cultural Psychology, 30(4), 501-526.

6. Bandura, A. (1977). Social learning theory. Englewood Cliffs.

7. Bazerman, M. H., \& Gino, F. (2012). Behavioral ethics: Toward a deeper understanding of moral judgment and dishonesty. Annual Review of Law and Social Science, 8, 85-104.

8. Beach, L. R. (1993). Broadening the definition of decision making: The role of prechoice screening of options. Psychological Science, 4(4), 215-220.

9. Beauchamp, T. L., \& Childress, J. F. (2009) Principles of Biomedical Ethics. 6th Edition, Oxford University Press, USA.

10.Becker, L. \& Becker, C. B. (2001). Encyclopedia of Ethics. Routledge, London and New York.

11.Betz, M., O'Connell, L., \& Shepard, J.M. (1989). Gender differences in proclivity for unethical behavior. Journal of Business Ethics, 8(5), 321-324.

12.Bommer, M., Gratto, C., Gravander, J., \& Tuttle, M. (1987). A behavioral model of ethical and unethical decision making. Journal of Business Ethics, 6(4), 265-280.

13.Bradford, J. L., \& Garrett, D. E. (1995). The effectiveness of corporate communicative responses to accusations of unethical behavior. Journal of Business ethics, 14(11), 875-892.

14.Brady, F. N. (1985). A Janus-Head Model of Ethical Theory: Looking Two Ways at Business/Society Issues. Academy of Management Review, 10(3), 568-576.

15.Çelikdemir, D. Z., \& Tukel, I. (2015). Incorporating Ethics into Strategic Management with regards to Generation Y's view of Ethics. Procedia - Social and Behavioral Sciences, 207(X), 528-535.

16.Chang, M. K. (1998). Predicting unethical behavior: a comparison of the theory of reasoned action and the theory of planned behavior. Journal of Business Ethics, 17(16), 1825-1834.

17.Daft, R. L. (2010). Management. US: South-Western Cengage Learning.

18.Denison, D.R. (2000). Organizational culture: Can it be a key lever for driving organizational change. In S. Cartwright \& C. Cooper (Eds.). The handbook of organizational culture. London: John.

19.Denison, D.R., \& Mishra, A.K. (1989). Organizational Culture and Organizational Effectiveness: A Theory and Some Preliminary Empirical Evidence. Academy of Management, 1, 168-172.

20.Donaldson, T. \& Preston, L. (1995). The Stakeholder Theory of the Corporation: Concepts, Evidence, and Implications. Academy of Management Review, 20, 65-91.

21.Drane, J. F. (2002) Honesty in Medicine: Should Doctors Tell the Truth? American Journal of Bioethics, 2, 14-17.

22.Gay, D. P. (2000). In Praise of Bureaucracy. Weber, Organization, Ethics. Sage: London.

23.El-banna, S., \& Child, J. (2007). Influences on strategic decision effectiveness: Development and test of an integrative model. Strategic Management Journal, 28(4), 431-453.

24.Ewin, K. (1991). Moral Status of the Corporation. Journal of Budru's Ethics, 10(10), 749-756.

25.Ferrell, O. C., Fraedrich, J., \& Ferrell (2010). Business Ethics: Ethical Decision Making \& Cases. US: South-Western Cengage Learning.

26.Ferrell, O. C., Fraedrich, J., \& Ferrell, L. (2008). Business Ethics. Boston: Houghton Mifflin Company.

27.Figuera, J., Greco, S. \& Ehrgott, M. (2005) Multiple Criteria Decision Analysis, State of the Art Surveys. New York: Springer.

28.Frankena, W. K. (1963). Ethics, Englewood Cliffs: Prentice-Hall

29.Freeman, S. J. M. \& Gieflnk, J.W. (1979). Moral Judgment as a Function of Age, Sex, and Stimulus. Journal of Psychology, 102, 43-47.

30.Furnham, A., \& Gunter, B. (1993). Corporate Assessment, Routledge, London

31.Gino, F. (2015). Understanding ordinary unethical behavior: why people who value morality act immorally. Current opinion in behavioral sciences, 3, 107-111. 
32. Heesen, B. (2015). Effective Strategy Execution: Improving Performance with Business Intelligence Management for Professionals (2nd ed.). Springer.

33.Hunt, S. D. \& Vitell, S. (1986). A General Theory of Marketing Ethics. Journal of Macromarketing, 6(Spring), 5-16.

34.Jones, T. M. (1991). Ethical decision making by individuals in organizations: An issue-contingent model. Academy of Management Review, 16(2), 366-395.

35.Kahn, W. A. (1990). Toward an agenda for business ethics research. Academy of Management Review, 15, 311-328.

36.Kanter, R. M. (1983). The change masters: Innovations for productivity in the American corporation. New York: Simon and Schuster.

37.Kaptein, M. (2011). Understanding unethical behavior by unraveling ethical culture. Human Relations, 64(6), 843-869.

38.Ketchen, D. J., Snow, C. C., \& Street, V. L. (2004). Improving firm performance by matching strategic decision-making processes to competitive dynamics. Academy of Management Executive, 18(4), 29-43.

39.Key, S., \& Popkin, S. J. (1998). Integrating ethics into the strategic management process: doing well by doing good. Management Decision, 36(5), 331-338

40.Kohlberg, L. (1969). Stage and Sequence: The Cognitive-Developmental Approach to Socialization, Handbook of Socialization Theory and Research. Chicago: Rand McNally.

41.Kohlberg, L. (1971). From Is to Ought (How to commit the Naturalistic Fallacy and Get Away with it in the Study of Moral Development). Cognitive Development and Epistemology, 151-235,

42.Li, D. Y., \& Liu, J. (2014). Dynamic capabilities, environmental dynamism, and competitive advantage: Evidence from China. Journal of Business Research, 67(1), 2793-2799.

43.Lundy, O., \& Cowling, A. (1996). Strategic Human Resource Strategy. London : Routledge,

44.Martins, N. (1987). Organisational culture in a financial institution (DPhil thesis). Pretoria: University of Pretoria.

45.Meredith, S. (2001). Champions of Change: How CEOs and their Companies are Mastering the Skills of Radical Change. Technovation, 21(10), 706.

46.Milkovich, G. T., \& Newman, J. M. (2002). Compensation (7th Eds). Boston, MA: McGraw Hill Irwin.

47.Militaru, C., \& Zanfir, A. (2012). The influence of organizational culture over the ethical principles in international businesses. International Journal of Academic Research in Accounting, Finance and Management Sciences, 2(Special 1), 26-33.

48.Ouchi, W. G. (1980). Markets, bureaucracies, and clans. Administrative Science Quarterly. 25, 129141.

49.Ovidiu-lliuta, D. (2014). The link between organizational culture and performance management practices: A case of IT companies from Romania. The Annals of the University of Oradea, 1130.

50.Páez, A., \& Scott, D. M. (2007). Social Influence on Travel Behavior: A Simulation Example of the Decision to Telecommute. Environment and Planning A: Economy and Space, 39(3), 647-665.

51.Rahahle, M. Y. (2017). Extent of Compliance with Code of Ethics and its Impact on Internal Audit Effectiveness. International Journal of Academic Research in Accounting, Finance and Management Sciences, 7(4), 40-61.

52.Rampersad, H. K. (2003). Total Performance Scorecard; Redefining Management to Achieve Performance with Integrity, Butterworth-Heinemann Business Books, Elsevier Science, Massachusetts.

53.Robbins, S. P. (1996). Organisational behaviour: Concepts, controversies, applications. Englewood Cliffs, NJ: Prentice-Hall.

54.Robertson, C. J. (2008). An analysis of 10 years of business ethics research in Strategic Management Journal: 1996-2005. Journal of Business Ethics, 80(4), 745-753.

55.Saaty, T. L. (2008). Decision making with the analytic hierarchy process. International Journal of Services Sciences, 1(1), 83-98.

56.Sanfey, A. G. (2007). Social decision-making: insights from game theory and neuroscience. Science, 318(5850), 598-602. 
57.Schein, E. H. (1996). Culture: The Missing Concept in Organization Studies. Administrative Science Quarterly, 41(2), 229-240.

58.Schein, E. H. (2004). Organizational Culture and Leadership. John Wiley \& Sons.

59.Senge, P. (1990). The fifth discipline: The art and science of the learning organization. New York: Currency Doubleday.

60.Şengül, M., Alpkan, L., \&Eren, E. (2015). Effect of Globalization on the Operational Performance: A Survey on SMEs in the Turkish Electric Industry. International Business Research, 8(7), 57-67.

61.Sims, R. R. (1992). The challenge of ethical behavior in organizations. Journal of Business Ethics, 11(7), 505-513.

62.Sinclair, A. (1993). Approaches to organisational culture and ethics. Journal of Business Ethics, 12(1), 63-73.

63.Soares, C. (2003). Corporate versus Individual Moral Responsibility. Journal of Business Ethics, $46(2), 143-50$.

64.Soltes, E. (2016). Why They Do It: inside the mind of the white-collar criminal. PublicAffairs

65.Soutar, G., McNeil, M. M., \& Molster, C. (1994). The impact of the work environment on ethical decision making: Some Australian evidence. Journal of Business Ethics, 13(5), 327-339.

66.Soyinka, K. A., Fagbayimu, M. O., Adegoroye, E., \& Ogunmola, J. O. (2017). Decision Usefulness and Financial Reporting: The General Public Perspective. International Journal of Academic Research in Accounting, Finance and Management Sciences, 7(4), 160-168.

67.Tang, T. L. P., \& Chiu, R. K. (2003). Income, money ethic, pay satisfaction, commitment, and unethical behavior: Is the love of money the root of evil for Hong Kong employees? Journal of Business Ethics, 46(1), 13-30.

68.Trevino, L. K., Butterfield, K. D., \& McCabe, D. L. (1998). The ethical context in organizations: Influences on employee attitudes and behaviors. Business Ethics Quarterly, 8(3), 447-476.

69.Tversky, A., \& Shaftr, E. (1992). Choice under conflict: The dynamics of deferred decision. Psychological Science, 6, 358-361.

70.Ward, L. \& Wilson, J. P. (1980). Motivation and Moral Developments Determinants of Behavioral Acquiescence and Moral Action. Journal of Social Psychology, 112, 271-286.

71.Watson, T. J. (2003). Ethical Choice in Managerial Work: The Scope for Moral Choices in an Ethically Irrational World. Human Relations, 56(2), 167-185.

72.Wheelen, T. L, \& Hunger, D. J. (2006). Concepts in Strategic Management and Business Policy. 10th ed. Pearson Education, Inc. New Jersey.

73.Wolfe, D. (1988). Is There Integrity in the Bottom Line: Managing Obstacles to Executive Integrity, in S. Srivasrva, ed., Executive Integrity: The Search for High Human Values in Organization Life (Jossey-Bass, San Francisco), pp. 140-171.

74.Wood, D. J. (1991). Corporate social performance revisited. Academy of Management Review. 16(4), 691-718. 